\title{
Diversity of Nematodes and Nematode Destroying Fungi as Influenced by Land Use in Taita Taveta, Kenya
}

\author{
P. M. Wachira ${ }^{1}$, J. W. Kimenju ${ }^{1}$, S. A. Okoth ${ }^{1} \&$ J. W. Kiarie ${ }^{1}$ \\ ${ }^{1}$ University of Nairobi, Nairobi, Kenya \\ Correspondence: P. M. Wachira, University of Nairobi, Nairobi, Kenya. E-mail: pwachira@uonbi.ac.ke
}

Received: June 27, 2013 Accepted: July 22, 2013 Online Published: November 15, 2013

doi:10.5539/jas.v5n12p154 URL: http://dx.doi.org/10.5539/jas.v5n12p154

\begin{abstract}
Land intensification is thought to lead to soil degradation and consequently to loss of soil biodiversity. A study was undertaken to assess the effect of land use on nematode community and nematode destroying fungi in Taita districts, Kenya. Soil samples were collected from land under various uses which were natural forest, plantation forest, tea, coffee, napier grass, fallow, maize/beans intercrop and horticultural crops production. Chemical analysis of the soil properties was done to determine the amount of carbon, nitrogen and potassium in every land use system. The level of carbon declined with land-use intensification with the highest organic carbon level of $7.6 \%$ being recorded in soils from the forest while land with high disturbance recorded $1.6 \%$ carbon. Similarly, the intensively cultivated soils had lower nitrogen and phosphorous levels compared to the forest. Nematode and nematode destroying fungi were isolated from the soil and identified. Eighty five isolates, distributed in eight genera and fourteen taxa of nematode destroying fungi were identified. The frequency of isolating nematode destroying fungi increased with increased in land use intensity. All the sampled land use types were significantly $\left(\mathrm{P}\right.$-value $\left.=3.81 \times 10^{-07}\right)$ different in occurrence of nematode destroying fungi. The ratios of free-living to plant parasitic nematodes were 5.18 and 0.54 in the natural forest and annual crop production systems, respectively. The frequency of isolation of nematode destroying fungi was positively correlated to abundance of plant parasitic nematodes.
\end{abstract}

Keywords: soil biodiversity, microorganisms, mesofauna, macrofauna, diversity, intensification

\section{Introduction}

The soil constitutes a complex microhabitat and contains diverse assemblages of organisms whose functions contribute to maintain life on earth (Lavelle, 1996; Giller et al., 1997; CBD, 2001). They are an important component of sustainable development given their potential as sources of new compounds for medicine, genes for plant improvement and provision of a wide range of ecosystem services (Alteri, 1999; Duelli et al., 2003). Although loss of biodiversity is gaining prominence all over the world, most of the conservation efforts have been directed to the larger plant and animal species of economic and aesthetic value. Smaller animals and lower plants, particularly those that inhabit the soil, have seldom been enlisted among endangered species.

Land degradation and soil fertility decline have been described as important constraints to food and nutritional security in Sub-Saharan Africa (Bationo, 2005). Despite the availability of high yielding and pest resistant varieties of major crops, there is still a big gap between the potential yield provided by scientific experiments and the yield obtained by farmers in Africa leading to a sizeable proportion of the population experiencing constant food and nutritional insecurity (Boutfirass et al., 1999). Undoubtedly, the misconception of the soil as a "lifeless" substrate has contributed to the poor understanding of soil biodiversity and its critical role to sustainability of agricultural productivity.

The diversity of soil-borne organisms and the total abundance of members of different trophic levels are largely controlled by the biophysical, chemical and hydrological conditions of the soil (Yeates \& Bongers, 1999). The soil as a habitat for biodiversity can be changed through management practices such as monoculture, tillage, drainage, application of agrochemicals, irrigation and organic mulch (Freckman \& Ettema, 1993; Yeates, 1999).

The soil biota is responsive to human-induced disturbances like deforestation, pollution and global environmental change leading to loss of primary functions such as cleansing potential wastes and pollutants, driving of element cycles, regulation of greenhouse gases, and natural regulation of pests and diseases (Swift \& Bignell, 2001). 
Biological processes are tightly linked with the maintenance of the soil structure, fertility and health, with higher sensitivity to changes than the physical and chemical characteristics of the soil. They could therefore serve as early warning indicators for appropriate interventions before irreversible effects on the integrity of the soil occurs. Given that food supply will greatly depend on intensifying agriculture, the effects of intensification on biodiversity and its associated functions should be established. It is assumed that land use intensification may lead to extinction of some species with the disastrous consequences of reduced ability of agricultural systems to contain undesirable effects and to withstand periods of stress. For instance, land use intensity was reported to affect arbscular mycorrhizal fungal species diversity in agroecosystems of central Europe (Oehl et al., 2003), while pollution from phosphorus fertilizer application reduced the diversity of arbscular mycorrhizal fungal (Renker et al., 2005). Previous studies have demonstrated activities of soil fauna contribute agricultural productivity (Beare et al., 1997).

The last decade has witnessed increased sensitivity to loss of diversity as a result of pollution, agricultural intensification, greenhouse effect, modification of global carbon and nitrogen cycles (Asner et al., 1997). This has led to recommendation for shift to sustainable agriculture production systems which are sensitive to soil biodiversity. However data is not readily available to support these recommendations. In particular, the effect of land use intensity on beneficial soil microorganism especially those that are antagonistic to plant parasitic nematodes is largely unknown.

Soil organisms remain among the least understood forms of life despite their critical importance to sustainability of ecosystem functions. Specifically, spatial distribution of different groups of soil organisms across land use systems of Kenya is largely unknown due to un-availability of methods for their assessment among other challenges (Wachira et al., 2008). This study was therefore carried out to determine the diversity and abundance of nematode destroying fungi and nematode community in different land-use systems in Taita, Kenya.

\section{Materials and Methods}

\subsection{Site Description}

The Taita Hills (lat $3^{\circ} 25^{\prime}$; long $38^{\circ} 20^{\prime}$ ) are situated in the Taita District in South-Eastern Kenya, Coast Province. It covers an area of $1000 \mathrm{~km}^{2}$ and they form the northernmost part of the Eastern Arc Mountains. They are isolated from other mountainous areas by the vast plains of Tsavo National Park and Tsavo plains. The hills experience the tropical moist highlands climate. The indigenous and planted forests of Taita hills occupy the upper highland regions, mainly mountains, while agro forestry and shrubs are found on the foot slopes, hills and uplands, while annual and perennials dominate the bench-terraced uplands. Mixed cropping and horticulture are dominant on the bottomlands. The soils were composed of high-humic A-horizons overlying pinkish acid sandy loam which were classified as are haplic acrisols, eutric cambisols, chromic luvisols and regosols. The soils are also characterized with high aluminum levels, low calcium levels, resulting in low cation exchange capacity.

\subsection{Soil Sampling}

Methods and criterion for soil sampling were as the protocol described by Moreira et al. (2008). Determination of the actual sampling plots was done on a systematic grid fixed at an interval of $200 \mathrm{~m}$ in the main land use systems of each site namely, coffee, tea, maize-based systems, napier, horticultural land, fallow, planted forest and natural forest. A total of 60 sampling points were pegged in the benchmark area and geo-referenced using a GPS.

The sixty sampling points were marked in circles measuring $3 \mathrm{~m}$ and $6 \mathrm{~m}$ radii from the center, where four and eight soil samples were taken at $0-20 \mathrm{~cm}$ depths (Figure 1). The auger was sterilized by dipping it in $70 \%$ ethanol between sampling points to avoid cross contamination. The soil samples were mixed thoroughly into a single composite sample for soil chemical analysis, isolation of nematode destroying fungi and extraction of nematodes. The soil samples were transported in polythene bags under cool condition to the laboratory where they were kept at $5^{\circ} \mathrm{C}$ before processing. 


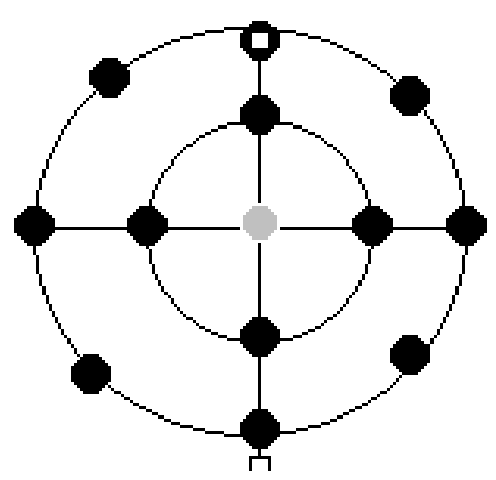

Figure 1. Soil sampling protocol for extraction of nematode destroying fungi and soil nematodes

Key Soil cores for microbes at 0-20 cm depth without litter. Circles radius: 3 and $6 \mathrm{~m}$.

Soil chemical analysis was conducted as described by Muya et al. (2009). Isolation of nematode destroying fungi was done using the soil sprinkle technique as described by Jaffee et al. (1996). Approximately one gram of soil from each sampling point was sprinkled onto the surface of water agar in petri dishes. Plant parasitic nematodes were added into the Petri dish as baits. The cultures were examined daily for trapped nematodes, trapping organs and conidia of the nematode destroying fungi that grew from the soil.

Soil nematodes were extracted from the soil using the sieving and centrifugation techniques as described by Jenkins (1964) and Kimenju et al. (2009).The extracted nematode families and genera were assigned to trophic groups (bacteria and fungi feeders, plant parasites, omnivores and predators as described by Yeates et al. (1993). Taxonomic groups were also assigned to colonizer-persistor c-p values, according to Bongers (1990).

\subsection{Data Analysis}

Soil property attributes and productivity indices were analyzed statistically using SPSS Statistical Computer Software Version 15.0, in which analysis of variance was carried out. The land use types were characterized by their chemical properties whose means were compared using ANOVA in Genstat Version 9.0. There was a further multivariate exploration where the soil chemical properties were constrained by the land use types and the results displayed in ordination plots. Nematode and nematode destroying datawere analyzed by calculating the frequency of occurrence, evenness, renyi profiles and the shannon diversity index (Kindt \& Coe, 2005). The Principal Component Analysis was conducted to estimate the factors that influence their occurrence. Multivariate analysis using ADE4 software was done on the temporal association of and the microbes and the results displayed in ordination plots (Thioulouse et al., 1997). All statistical tests were conducted at the level of significance of $P \leq 0.05$.

\section{Results}

\subsection{Soil Characterization}

The main land use systems found in the study were natural and planted forests, fallow/grassland, cropland under tea, coffee, maize/bean and vegetable production. The land use systems were found on landscapes with varying biophysical and climatic characteristics. The soil types were identified as mainly acrisols, cambisols, luvisols and regosols which are very farm and compact. From the results, the chemical and physical characteristics of the soil indicated that, except for the sodium $(\mathrm{Na})$ all the other parameters were significantly $(\mathrm{P}<0.005)$ different across the land use types. Nitrogen, phosphorus and pottasium quantities (NPK) varied significantly across the land uses. The forests land uses recorded the highest amount of nitrogen, with the indigenous forests recording $0.5 \%$ planted forest 0.4 while fallow and nappier recorded $0.3 \%$ with 0.2 being recorded in coffee, maize and horticulture land uses. Potassium levels were high (0.76) in nappier land use and least (1.17) in planted forest. Horticulture, fallow, maize/bean indigenous forest and coffee recorded $0.56,0.4,0.38,3,4$ and 0.3 in that decreasing order. The highest level of phosphorus was also nappier fields. The highest percentage carbon was recorded in the indigenous forest, with a record of $2.7 \%$ followed by $2.3,1.9,1.8$ and 1.7 in planted forests, nappier, coffee and horticulture and fallow and maize/bean respectively in that decreasing order. 
Table 1. Effect of land use types on soil chemical properties in Taita Taveta, Kenya

\begin{tabular}{|c|c|c|c|c|c|c|c|c|c|c|c|c|c|}
\hline 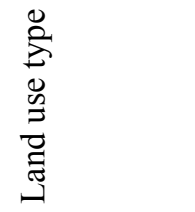 & 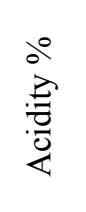 & 売 & $\dot{0}^{\circ}$ & $\dot{0}^{\circ}$ & $\tilde{U}$ & 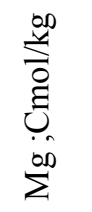 & $\tilde{z}$ & 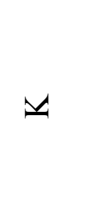 & $a$ & $\begin{array}{l}\Xi \\
\stackrel{\Xi}{2} \\
\text { స్ }\end{array}$ & $\tilde{J}$ & $\sum^{E}$ & iI \\
\hline Coffee & 0.4 & 4.8 & 0.2 & 1.8 & 2.1 & 2.3 & 0.2 & 0.3 & 14.4 & 3.8 & 0.7 & 30 & 41.1 \\
\hline Fallow & 0.8 & 4.4 & 0.3 & 1.7 & 3.5 & 2.4 & 0.3 & 0.4 & 42.1 & 1.9 & 0.8 & 40 & 48.2 \\
\hline Horticulture & 0.3 & 4.9 & 0.2 & 1.8 & 2.34 & 2.4 & 0.3 & 0.56 & 53.4 & 4.1 & 0.94 & 80 & 49.8 \\
\hline $\begin{array}{l}\text { Natural } \\
\text { Forests }\end{array}$ & 1.1 & 4.0 & 0.5 & 2.7 & 2.60 & 1.2 & 0.3 & 0.34 & 27.6 & 3.6 & 1.33 & 70 & 76.7 \\
\hline Maize/bean & 0.3 & 4.6 & 0.2 & 1.7 & 2.57 & 2.2 & 0.2 & 0.38 & 12.5 & 4.5 & 1.90 & 70 & 31.1 \\
\hline Napier & 0.3 & 4.9 & 0.3 & 1.9 & 3.40 & 3.7 & 0.3 & 0.76 & 58.3 & 6.2 & 1.76 & 50 & 44.1 \\
\hline $\begin{array}{l}\text { Planted } \\
\text { Forest }\end{array}$ & 2.0 & 3.5 & 0.4 & 2.3 & 2.36 & 1.2 & 0.3 & 0.17 & 5.8 & 4.6 & 1.08 & 75 & 89.4 \\
\hline P-value & $\begin{array}{l}<.00 \\
1\end{array}$ & $\begin{array}{l}<.00 \\
1\end{array}$ & $\begin{array}{l}<.00 \\
1\end{array}$ & $\begin{array}{l}<.00 \\
1\end{array}$ & $\begin{array}{l}0.01 \\
8\end{array}$ & $\begin{array}{l}<.00 \\
1\end{array}$ & $\begin{array}{l}0.28 \\
5\end{array}$ & $\begin{array}{l}0.00 \\
2\end{array}$ & $\begin{array}{l}0.01 \\
9\end{array}$ & $\begin{array}{l}0.00 \\
2\end{array}$ & $\begin{array}{l}0.00 \\
1\end{array}$ & $\begin{array}{l}0.00 \\
6\end{array}$ & $\begin{array}{l}<.00 \\
1\end{array}$ \\
\hline
\end{tabular}

As shown in the table, the soil acidity was lowest in indigenous forest and highest in planted forest.

\subsection{Nematode Destroying Fungi}

Nematode destroying fungi were recorded in all the land uses under investigation in this study. In total, eighty five isolates of nematode destroying fungi were recorded. The species isolated were Athrobotrys oligospora, Athrobotrys dactyloides, Monacrosporium cionopagum, Athrobotrys superb, Harposporium aungulilae , Acrostalagums obavatus, Nematoctonus georgenious, Haptoglosa heterospora, Dactyllela lobata and Myzocytium $s p$. The general Arthrobotrys represented $61 \%$ of all the recorded isolates and occurred in all the land uses while the least genera was Myzocytium which represented only 1.2\% of the total recorded isolates (Table 2) The occurrence of these fungi was significantly $\left(\mathrm{p}\right.$-value $\left.=3.81 \times 10^{-07}\right)$ different among the land use types.

The diversity of nematode destroying fungi was highest in agricultural fields compared to the fallow and the natural forest. Land use under horticultural crops was the most diverse, followed by maize/bean, nappier, fallow and then the least was the forests. From the results, it was evident that evenness was also affected by land use intensity with the highest evenness being recorded in the natural forest and lowest in the vegetable gardens. In comparison to evenness, species richness was highest in the intensively cultivated land under vegetable gardens with a species richness of nine being recorded while the least was recorded in the natural forest (Table 3 ).

Table 2. Percentage frequency of nematode destroying fungi isolated from soil samples in Taita Taveta, Kenya

\begin{tabular}{llcc}
\hline Rank & Species & No. of isolates & \% Frequency of isolation \\
\hline 1 & Athrobotrys oligospora & 29 & 34.1 \\
2 & Athrobotrys dactyloides & 15 & 17.6 \\
3 & Monacrosporium cionopagum & 10 & 11.8 \\
4 & Athrobotrys superba & 8 & 9.4 \\
5 & Harposporium aungulilae & 7 & 8.2 \\
6 & Acrostalagums obavatus & 5 & 5.9 \\
7 & Nematoctonus georgenious & 4 & 4.7 \\
8 & Haptoglosa heterospora & 3 & 3.5 \\
9 & Dactyllela lobata & 3 & 3.5 \\
10 & Myzocytium sp & 1 & 1.2 \\
\hline
\end{tabular}

The principal component analysis (PCA) showed that two main factors accounted for $84.12 \%$ of the occurrence of nematode destroying fungi in the study area with the main factor, explaining $60.77 \%$ while the second factor 
explaining 23.35\%. Factor one separated land uses under intensive cultivation from others. The intensively cultivated land uses included the vegetable and the maize bean which receive regular application of commercial fertilizers, pesticides and herbicides while land uses without any soil disturbance are the natural forests, shrub and nappier (Figure $2 \mathrm{a}$ and $\mathrm{b}$ ).

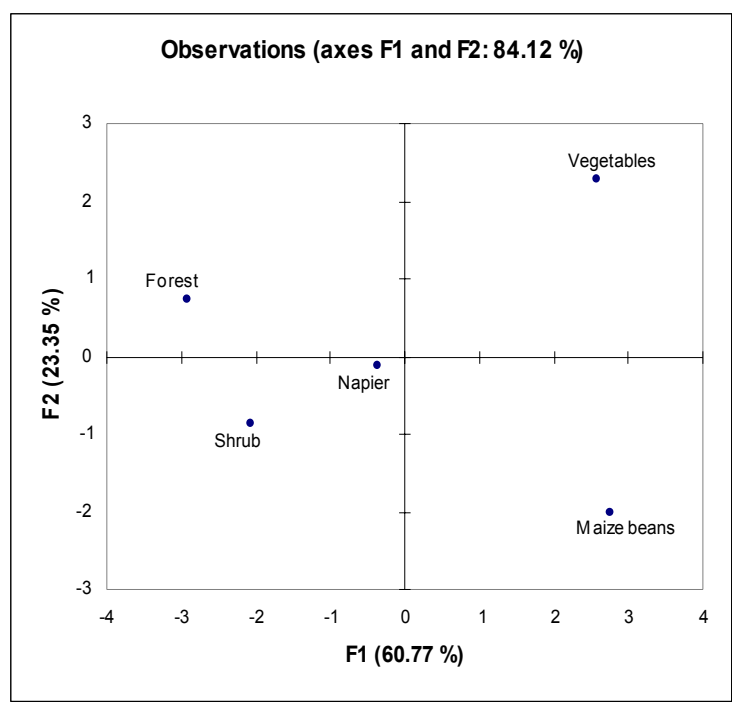

$2 \mathrm{a}$

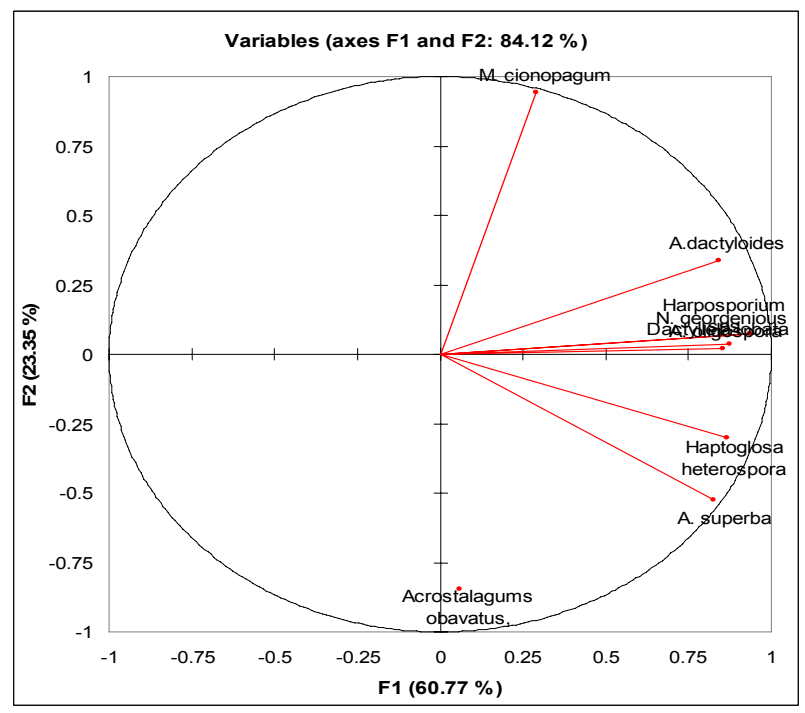

$2 \mathrm{~b}$

Figure $2 \mathrm{a}$ and $\mathrm{b}$. shows a principle component analysis indicating the effect of land use on occurrence of nematode destroying fungi

\subsection{Soil Nematodes}

The total nematode numbers varied significantly $(\mathrm{P}<0.05)$ among the land use systems in the study site. Nematode abundance was highest in the coffee, followed by fallow fields, then vegetable fields, maize/bean, natural forest and finally least in planted forest. Among the agricultural land uses, nematode abundance was highest in land under coffee, vegetables and then maize/bean fields. The abundance of plant parasitic nematodes was highest under coffee and maize and vegetables and least in fallow, planted forets and natural forest in that declining order. The free living nematodes were abundant in the natural forest and the least population was recorded in the vegetable fields. The ratio of free-living nematodes to plant parasitic nematodes showed a general decline in land under agricultural use, reflecting dominance of plant parasitic nematodes. The natural forest recorded the highest number of free living nematodes and the least plant parasitic nematodes with a ration of 4.01 of free living to plant parasitic nematodes. Although the coffee land use had the highest number of plant parasitic nematodes, it recorded high number (419) of free living nematodes, being second to forests and fallow. The proportion of free-living to plant parasitic nematodes was highest in the natural forests followed by the plantation forests while it was least in vegetables and maize respectively (Table 3 ).

Table 3. Comparison of plant parasitic and free-living nematodes in soils under different uses in Taita Taveta

\begin{tabular}{llll}
\hline Land use & PPN & FL & FL:PPN \\
\hline Planted forest & 353 & 526 & 1.49 \\
Coffee & 948 & 419 & 0.44 \\
Maize/bean & 938 & 120 & 0.13 \\
Fallow & 796 & 458 & 0.57 \\
Natural forest & 189 & 759 & 4.01 \\
Vegetable & 915 & 191 & 0.21 \\
LSD $\left(\mathrm{p}_{<0.05)}\right.$ & 122 & 137 & \\
\hline
\end{tabular}


PPN-Plant parasitic nematodes, FL-Free-living nematodes, FL: PPN-Ratio of free-living to plant parasitic nematodes.

As shown in the table above, free livinng nematodes were more frequent indisrurbed systems compared the disturbed.

\section{Discussion}

From this study, it is evident that the soil chemical characteristics are significantly different across the land use types. Low levels of nitrogen of were recorded in cultivated lands compared to the forests. This could be attributed to the continuous cultivation and inadequate soil management activities in cultivated fields especially in horticultural areas. This leads to loss of nitrogen stocks in cultivated land compared to the forests. In a related study, the productivity index (PI) reduced with land use intensity with $15-20 \%$ being recorded in horticultural and maize-based systems compared to 40-50\% in the natural forest and grassland land uses (Muya et al., 2009).

This study, has demonstrated that land use has a significant impact on nematodes destroying fungi and soil nematodes. The study acknowledges the occurrence of nematode destroying fungi in the soil and the role the group plays in regulation of the population plant parasitic nematodes. The fungi that were isolated exhibited several mechanisms of capturing and destroying plant parasitic nematodes which included constricting rings, adhesive nets, and non-constricting rings. Birgit et al. (2002), reported that nematode destroying fungi are cosmopolitan group of fungi, and occurs at different densities and diversities in various land use systems. Widespread occurrence and abundance of the fungi is thought to be an indicator of great potential that can be exploited in the management of plant parasitic nematodes as well as animal nematodes (De \& Sanyal, 2009). Contrary to expectation that beneficial microorganisms decrease with increase in intensity of land use (Vandermeer et al., 1998), the diversity of the nematode destroying fungi was higher in the vegetable gardens compared to the forest ecosystem. In less disturbed land use systems such as the forest and shrub land, only a few isolates of nematode destroying fungi were recovered.

The nematode diversity decreases with intensity of land cultivation or soil disturbance. The natural forest can be considered as the reference point since it has the highest diversity and abundance of nematodes of different trophic levels. Natural forests ecosystems are characterized by high plant diversity and high organic matter content long-term freedom from human interference including application of agrochemicals have high aboveground diversity and soil organic matter content. Disturbance of the natural forest through felling of indigenous trees, followed by establishment of single species plantations resulted in a decline in nematode abundance and species richness. According to Bloemers et al. (1997), disturbance not only changes species but also the species composition. Considering the biological characteristics of nematodes and the diversity exhibited within their community, variability would be expected in the response of members of different trophic levels to disturbance. Indeed, free-living nematodes are more sensitive to ecosystem disturbances making them potential bio-indicators of the changes in the soil environment (Bongers \& Bongers, 1998). Soil management practices have been demonstrated to be among the causes of the alterations of soil fauna population structure as well as the microbial community (Ayuke et al., 2009).

The observed variations in soil properties should also influence the occurrence and distribution of soil organisms. Hypothetically, the forest soils due to their high levels of organic carbon and nitrogen, should offer better habitats for many organisms since carbon forms the basic feed of most organisms. Grasslands and napier grass have also proved to improve the accumulation of some soil nutrients meaning that they can be good interventions for managing soil nutrients when planted in rotations or left as fallow crops.

\section{Conclusion}

Using the natural forest as the point of reference, maize/bean and horticulture land uses are intensively cultivated, hence the high diversity of nematode destroying fungi. The same trend was also observed for plant parasitic nematodes. Natural forest recorded the highest number of free living nematodes. It is therefore surprising that areas that recorded the highest population and diversity of nematode destroying fungi also recorded the highest number of plant parasitic nematodes. This may be an indicator of loss of function of nematode destroying fungi in habitats that are subject to human disturbance.

\section{References}

Altieri, M. A. (1999). The ecological role of biodiversity in agro-ecosystems. Agriculture, Ecosystems and Environment, 74, 19-31. http://dx.doi.org/10.1016/S0167-8809(99)00028-6 
Asner, G. P., Seastedt, T. R., \& Townsend, A. R. (1997). The decoupling of terrestrial carbon and nitrogen cycle: Human influences on land cover and nitrogen supply are altering natural biogeochemical links in the biosphere. Bioscience, 47, 226-234. http://dx.doi.org/10.2307/1313076

Ayuke, F. O. Karanja, N. K., Muya, E. M., Musombi, B. K., Mungatu, J., \& Nyamasyo. G. H. N. (2009). Macrofauna diversity and abundance across different land use systems in Embu, Kenya. Tropical and Subtropical Agroecosystems, 11(2), 371-384

Bationo, A. (2008). Integrated soil fertility management options for agricultural intensification in the Sudano-Sahelian Zone of West Africa. Pbl. Academy Science Publishers in association with Tropical Soil Biology and Fertility (TSBF) of CIAT.

Birgit, H., Hans, B. J., \& Anders, T. (2002). Nematophagous Fungi. Encyclopedia of Life Sciences. Mackmillan Publishers Ltd.

Bongers, T. (1990). The maturity index: an ecological measure of environmental disturbance based on nematode species composition. Oecologia, 83, 14-19. http://dx.doi.org/10.1007/BF00324627

Bongers, T., \& Bongers, M. (1998). Functional diversity of nematodes. Applied Soil Ecology, 10, 239-251. http://dx.doi.org/10.1016/S0929-1393(98)00123-1

Boutfirass, M., \& Gharous, M. E. L. (1999). Optimizing soil water use research in deficient water environments of Morocco. In N. van Duivenbooden, M. Pala, C. Studer, \& C. L. Bielders (Eds), Efficient Soil water Use: the key to sustainable crop production in the dry areas of West Asia, North and Sub-Saharan Africa. Proceedings of the workshop organized by the optimizing soil water use Consortium, Niamey, Niger, April $26^{\text {th }}-30^{\text {th }} 1998$ and in Ammam, May $9^{\text {th }} 13^{\text {th }} 1999$.

Bulluck, L. R., Barker, K. R., \& Ristaino, J. B. (2002). Influences of organic and synthetic soil fertility amendments on nematode trophic groups and community dynamics under tomatoes. Applied Soil Ecology, 21(3), 233-250. http://dx.doi.org/10.1016/S0929-1393(02)00089-6

CBD. (2001). Convention on Biological Diversity: Agricultural biological diversity, soil biodiversity and sustainable agriculture. Food and Agriculture Organization (FAO) paper. UNEP/CBD/SBSSTA/7/INF/11.

De, S., \& Sanyal, P. K. (2009). Biological control of helminth parasites by predatory fungi. Vetscan, 4, 1-8.

Duelli, P., \& Obrist, M. K. (2003). Biodiversity indicators: the choice of values and measures. Agric. Ecosyst. Environ, 98, 87-98. http://dx.doi.org/10.1016/S0167-8809(03)00072-0

Freckman, D. W., \& Ettema, C. H. (1993). Assessing nematode communities in agro ecosystems of varying degrees of human intervention. Agriculture, Ecosystems and Environment, 45, 239-261. http://dx.doi.org/10.1016/0167-8809(93)90074-Y

Gams, W. (1992). The analysis of communities of saprophytic micro fungi with special reference to soil fungi. In W. Winterhoff (Ed.), Fungi in Vegetation Science (pp. 183-223). Kluwer Academic publishers, Dordrecht. http://dx.doi.org/10.1007/978-94-011-2414-0_7

Giller, K. E., Cadisch, G., Ehaliotis, C., Sakala, W. D., \& Mafongoya, P. L. (1997). Building soil nitrogen capital in Africa. In R. J. Buresh, P. A. Sanchez, \& F. Calhoun (Eds), Replenishing Soil Fertility in Africa (pp. 151-192). SSSA Special publication Number 51.

Jaffee B. A., Strong, D. R., \& Muldoon, A. E. (1996). Nematode trapping fungi of natural shrubland: Tests for food chain involvement. Mycologia, 88, 554-364. http://dx.doi.org/10.2307/3761149

Jenkins, W. R. (1964). A rapid centrifugal-floatation technique for separating nematodes from soil. Plant Disease Report, 48, 692.

Kimenju, J. W., Karanja, N. K., Mutua, G. K., Rimberia, B. M., \& Wachira, P. M. (2009). Nematode community structure as influenced by land use and intensity of cultivation. TropIcal and Subtropical Agroecosystems, 11(2), 353-360. Retrieved from Uonbi.ac.ke:8080/xmlui/handle/123456789/12158

Kindt, R., \& Coe, R. (2005). Tree diversity analysis. A manual and software for common statistical methods for ecological and biodiversity studies. Nairobi: World Agro-forestry Center (ICRAF).

Lavelle, P. (1996). Diversity of soil fauna and ecosystem function. The convention on Biological Diversity, Diversities and a new focus on Soil Biodiversity: Biology International No. 33, July, 1996.

Moreira, F. M. S., Huising, E. J., \& Bignell, D. E. (2008). A Handbook of Tropical Soil Biology: Sampling and Characterization of Below Ground Biodiversity. Earthscan, UK 218 pp. ISBN: 9781844075935 
Muya, E. M., Karanja, N., Okoth, P. F. Z., Roimen, H., Munga'tu, J., Mutsotso, B., \& Thuranira, G. (2009). Comparative description of land use and characteristics of belowground biodiversity benchmark sites in Kenya. Tropical and Subtropical Agroecosystems, 11, 263-275. Retrieved from http://Uonbi.ac.ke:8080/xmlui/handle/123456789/12165

Muya, E. M., Karanja, N., Okoth, P. F. Z., Roimen, H., Munga'tu, J., Mutsotso, B., \& Thuranira, G. (2009). Comparative description of land use and characteristics of belowground biodiversity benchmark sites in Kenya. Tropical and Subtropical Agroecosystems, 11(2), 263-275

Swift, M. J., \& Bignell, D. (2001). Standard methods for assessment of soil biodiversity and land use practice. ASB Lecture Note 6B, ICRAF, Bogor, Indonesia. Retrieved from http://www.icraf.cigar.org/sea

Thioulouse, J., Chessel, D., Dolédec, S., \& Olivier, J. M. (1997). ADE-4: a multivariate analysis and graphical display software. Statistics and Computing, 7, 75-83. http://dx.doi.org/10.1023/A:1018513530268

Vandermeer, J., van Noordwijk, M., Anderson, J. M., Ong, C., \& Perfecto, I. (1998). Global change and multi-species agro ecosystems: Concepts and issues. Agriculture, Ecosystem and Environviroment, 67(1), 1-22. http://dx.doi.org/10.1016/S0167-8809(97)00150-3

Wachira, P. M., \& Sheila, O. (2009). Use of nematode destroying fungi as indicators of land disturbance in Taita Taveta, Kenya. Tropical and Subtropical Agro-ecosystem, 11(2), 313-321. Retrieved from Uonbi.ac.ke:8080/xmlui/handle/123456789/14583

Wachira, P. M., Kimenju, J.W., Okoth, S. A., \& Mibey, R. K. (2009). Stimulation of nematode - destroying fungi by organic amendments applied in management of plant parasitic nematode. Asian Journal Plant Sciences, 8(2), 153-159. http://dx.doi.org/10.3923/ajps.2009.153.159

Yeates, G. W. (1999). Effects of plants on nematode community structure. Annual Review of Phytopathology, 37, 127-49. http://dx.doi.org/10.1146/annurev.phyto.37.1.127

Yeates, G. W., \& Bongers, T. (1999). Nematode diversity in agroecosystems. Agriculture Ecosystem and Environment, 74, 113-135. http://dx.doi.org/10.1016/S0167-8809(99)00033-X

\section{Copyrights}

Copyright for this article is retained by the author(s), with first publication rights granted to the journal.

This is an open-access article distributed under the terms and conditions of the Creative Commons Attribution license (http://creativecommons.org/licenses/by/3.0/). 